\title{
Strategy For Development of Middle Small Micro Businesses With Coaching and Mentoring Approaches In Baturaja City
}

\author{
Rani Anwar ${ }^{1}$, Titie Syahnaz Natalia ${ }^{2}$ \\ \{ranianwar20@gmail.com ${ }^{1}$,syahnaztitie@gmail.com² ${ }^{2}$ \\ Management Study Program, Faculty Of Economics and Business, Baturaja Univesity ${ }^{1,2}$
}

\begin{abstract}
Micro, small and medium businesses have an important role for the economy in Indonesia. One of them is economic growth in employment and distribution of development results. The Indonesian government needs to foster MSMEs by collaborating through the Office of Cooperatives and SMEs in each City. MSMEs also face various problems, including limited working capital, low quality of human resources, and a lack of mastery in science and technology. The method used in this research is descriptive method. The study population is MSMEs in the City of Baturaja. The data collection techniques used are observation, interviews and questionnaires while the data analysis technique uses SWOT analysis and then formulates strategies to overcome them. The purpose of the training and assistance of small and medium businesses and cooperatives in the City of Baturaja is expected to increase the income so that welfare is also increasing.
\end{abstract}

Keywords: MSME, Development, Coaching, Mentoring

\section{Introduction}

In the current era of globalization, there are many ways to develop a country's economy. One way to advance the economic development of a country is by contributing through Small, Micro and Medium Enterprises (MSMEs). MSMEs can also develop the potential of a region or region, so that it can increase a business, absorb labor, and distribute development results. Empowering MSMEs is one way to increase the income of low-income groups, with the aim of reducing income gaps through business management skills.

MSMEs can develop if maximum development is carried out. For this reason, a development strategy is needed so that MSMEs can develop according to expectations. A business can develop if the leader is able to mobilize all the potential that is owned by each region / region. Both the potential for human resources and the potential for natural resources owned.

The development of MSMEs is essentially a shared responsibility between the government and society. According to Alyas, et al (2017) by looking at the problems faced by MSMEs, efforts are needed such as: (a) Creating a conducive business climate; (b) Capital assistance; (c) Business protection; (d) Partnership Development; (e) Training; (f) Developing promotions; and (g) Developing equal cooperation [1].

In OKU Regency, MSMEs are the backbone of the economy. Where the number of MSMEs in OKU Regency is currently 8,568, with details of Micro Enterprises (having capital of Rp. 50 million and below, excluding land and buildings), the total is 4,555 units and are scattered throughout the District in OKU Regency. Furthermore, Small Enterprises (having a capital of Rp. 60 million - Rp. 
500 million excluding land and buildings) currently reaches 3,612 units. Meanwhile, Medium Enterprises (having a capital of IDR 50 million to 10 billion excluding land and buildings) currently has 383 units.

Based on the pre-survey that has been conducted with many MSMEs players in Baturaja City, an MSMEs coaching approach is needed. This can be seen from the number of MSMEs actors who face various problems including limited working capital, low quality of human resources, and lack of mastery of science and technology. Not only that, lack of clarity about business prospects and planning, and how to market or promote products to be marketed. Therefore, it is necessary to have an appropriate competitive strategy, one of which is managing resources effectively and efficiently. Every MSMEs is required to have high competitiveness, so it must improve itself both in terms of quality and quantity, competent human resource capacity (HR), especially control of the economy.

As we know, the MSMEs business is one of the most profitable sectors in entrepreneurship. However, since the outbreak of the corona virus, of course this has had an impact on the purchasing power of the community itself. This is one of the reasons why the sales of MSMEs, especially in Baturaja City, have decreased. Therefore, coaching must be carried out such as conducting coaching in collaboration with the cooperative office, and providing direct assistance with MSMEs actors in Baturaja City.

This study aims to determine the development of MSMEs in OKU Regency with a development strategy through coaching and mentoring approaches. Because, there are still MSMEs that are not well developed. So, the MSMEs did not go as expected. For example, many MSMEs players are confused in marketing their products. They don't know what strategy to use in promoting what they sell. Based on the above, there are two research questions formulated in this study; (1) development strategy with a coaching approach; (2) Development strategy with a mentoring approach.

\section{Method}

This type of research method used by the author is descriptive method. Descriptive method is intended to describe a state or phenomenon as it is. Descriptive research is research on problems in the form of current facts from a population which includes assessing attitudes or opinions of individuals, organizations, circumstances, or procedures. Then compiled systematically and then analyzed to create conclusions, to answer the formulation of problems about development strategies with coaching and mentoring approaches.

The population in this study were MSMEs in the city of Baturaja. Determination of the sample of respondents using purposive sampling method. The sample is selected based on certain considerations [2]. The MSMEs sample criteria used are as follows:

1. Owning assets of IDR 50,000,000 - IDR 10,000,000,000.

2. Owning a maximum turnover of 50 billion per year

3. Owning a workforce of 5-250 people

4. Business based processing both home industry, agriculture and fisheries.

\subsection{Data Collection Technique}

Data collection techniques were carried out in this study using the following techniques [3]:

1. Observation 
Research can obtain data by studying and understanding behavior directly.

2. Interview

An interview is a meeting of two people to exchange information and ideas through question and answer, so that meaning can be constructed in a particular topic.

3. Questionnaires

The questionnaire is in the form of distributing questionnaires given to respondents in the study.

\subsection{Data Analysis Technique}

The data analysis technique used in this study was a SWOT analysis and then formulated a strategy to overcome it.

\section{Results}

The results and discussion of this study are based on questionnaires. The population and respondents in the questionnaire are MSMEs business actors in Baturaja City.

MSMEs in Baturaja City have considerable potential. This can be seen from the many natural resources that are owned. In the Baturaja area, especially the Ogan River, there are abundant fish products that can be used by business actors to be processed into pempek, crackers, tekwan, and others. Furthermore, it is also supported by plantation products such as coffee plantations, rubber gardens, oil palm plantations, and other plantation products that have advantages in terms of quality and quantity.

In this research, the technical data analysis used is the SWOT analysis to systematically identify various factors to formulate effective business development strategies to improve the competitiveness of MSMEs in Baturaja City.

SWOT analysis according to Sudaryono (2015: 191) is a market analysis which is an assessment process that includes market segmentation, marketing research, and forecasting product sales [4]. In this marketing strategy, the SWOT formula (Strength, Weakness, Opportunity, and Treat) can be used.

The following is a breakdown of the strengths, weaknesses, opportunities and threats in developing effective businesses to increase the competitiveness of MSMEs in Baturaja City:

1. Internal factors that come from the MSMEs business in the city of Baturaja in the form of strengths and weaknesses of MSMEs in Baturaja City

a. Strength consists of:

1) Legality and product permits are recognized by the public

2) Product prices that are able to compete with similar products

3) Raw materials are easy to obtain

4) Cheap raw material prices

5) Improving the quality of the workforce by providing training and mentoring

6) Changing equipment that is more sophisticated and efficient to facilitate the production process so that it can support MSME businesses

b. Weaknesses consist of:

1) Capital limitations owned by MSME actors

2) Lack of understanding from MSME actors about business management, business strategies, systems and product marketing processes

3) Most of the MSMEs in Baturaja City have not registered with the Business Association in Baturaja City 
4) Lack of marketing networks and information technology to support development for MSMEs

5) Availability of human resources who have expertise and experience

\subsection{Analysis of Identification and Description of MSMEs Development in Baturaja City Product Indicators}

Table 1. Product Indicators: 2020 Data Processing

\begin{tabular}{clcc}
\hline No & \multicolumn{1}{c}{ Statements } & Percentages & Criteria \\
\hline 1 & Product Legality & $95 \%$ & Effective \\
2 & Raw Product Materials Easy to get & $90 \%$ & Effective \\
3 & There is product differentiation & $80 \%$ & Effective enough \\
4 & Performing product quality checks & $90 \%$ & Effective \\
5 & means of production availability & $75 \%$ & Effective enough \\
\hline
\end{tabular}

From table 1, the product indicators show that the legality of the product is $95 \%$, the product raw materials and product quality checks are easy to get by $90 \%$, said to be effective. Therefore, MSMEs business actors in Baturaja City must maintain this. Meanwhile, product indicators regarding product differentiation by $80 \%$ and availability of production tools by $75 \%$ are said to be quite effective. For this reason, business actors must pay more attention in terms of product differentiation, how products can compete fairly with other products. In addition, some MSMEs business actors in Baturaja City are still hampered by the availability of manual production tools. In this case, there needs to be a role from the local government to support the production process.

\subsection{Promotion Indicator}

Table 2. Promotion Indicators: 2020 Data Processing

\begin{tabular}{clcc}
\hline No & \multicolumn{1}{c}{ Statements } & Percentages & Criteria \\
\hline 1 & Promotion Range & $80 \%$ & Effective enough \\
2 & Promotional Appeal & $80 \%$ & Effective enough \\
3 & $\begin{array}{l}\text { The quality of messages delivery in } \\
\text { promotional activities }\end{array}$ & $85 \%$ & Effective enough \\
4 & $\begin{array}{l}\text { The quantity of ads display in } \\
\text { promotional media }\end{array}$ & $85 \%$ & Effective enough \\
5 & Promotion strategy & $80 \%$ & Effective enough \\
\hline
\end{tabular}

From table 2, the promotion indicators show that the range of promotion, promotional attractiveness, quality of message delivery in promotional activities, quality of advertising in promotional media and promotion strategies are quite effective. For this reason, there is a need for development through coaching and mentoring to MSMEs business actors in Baturaja City from the local Regional Government. With the aim that the promotion reaches the public, so that people know about the products being marketed.

\subsection{Price Indicator}

Table 3. Price Indicators: 2020 Data Processing

\begin{tabular}{llll}
\hline No & Statements & Percentages & Criteria \\
\hline
\end{tabular}




\begin{tabular}{llll}
\hline 1 & Prices affordability & $90 \%$ & Effective \\
2 & $\begin{array}{l}\text { Price matching with perceived } \\
\text { benefits }\end{array}$ & $92 \%$ & Effective \\
3 & $\begin{array}{l}\text { Prices Comparison offered by } \\
\text { competitors' products }\end{array}$ & $95 \%$ & Effective \\
4 & $\begin{array}{l}\text { Price comparison with product } \\
\text { quality } \\
\text { Capital assistance from the local } \\
\text { government }\end{array}$ & $85 \%$ & Effective Enough \\
\hline
\end{tabular}

From table 3 regarding the price indicators above, it shows that price affordability is $90 \%$, price compatibility with perceived benefits is $92 \%$, the price comparison offered by competitor products is $95 \%$, and the price comparison with product quality is $93 \%$ with the criteria being effective. For this reason, MSMEs business actors in Baturaja City continue to maintain prices that are affordable by the community or consumers with the aim of the community or consumers remaining and becoming regular customers. Meanwhile and capital assistance from local governments shows $85 \%$ is quite effective. In this case, the government needs to pay more attention to providing capital assistance to MSMEs business actors in Baturaja City in terms of facilitating the lending of funds / money / business capital to banks or cooperatives. This makes it easier for business actors to open or run their business.

\subsection{Place Indicator}

Table 4. Location Indicators: 2020 Data Processing

\begin{tabular}{|c|c|c|c|}
\hline No & Statements & Percentages & Criteria \\
\hline 1 & $\begin{array}{l}\text { Selection of a strategic location or } \\
\text { place }\end{array}$ & $90 \%$ & Effective \\
\hline 2 & Ease of access and transportation & $92 \%$ & Effective \\
\hline 3 & $\begin{array}{l}\text { The location of the business can be } \\
\text { seen by consumers }\end{array}$ & $95 \%$ & Effective \\
\hline 4 & Having an inventory warehouse & $80 \%$ & Effective Enough \\
\hline 5 & $\begin{array}{l}\text { The role of local government in the } \\
\text { selection and establishment of } \\
\text { business premises }\end{array}$ & $82 \%$ & Effective Enough \\
\hline
\end{tabular}

From table 4 , the place indicator shows that the choice of a strategic location or place is $90 \%$ effective, easy access and transportation is $92 \%$ effective, the business location can be seen by consumers as $95 \%$ effective. This is good enough, business actors only need to maintain it, because its strategic location is one of the main attractions for consumers because it is easy to reach. Meanwhile, the statement of having an inventory of $80 \%$ is quite effective. And the role of local government in the selection and establishment of business premises was $82 \%$ quite effective. In this case, the local regional government needs to coordinate again for business actors who do not yet have a warehouse for inventory and also when business actors request permission to establish business premises need to be considered so that they are not mistaken in establishing a business place.

External factors that come from the MSMEs business in the city of Baturaja in the form of opportunities and threats for MSMEs in Baturaja City

a. Opportunities consist of: 
1) Having potential natural resources compared to other areas

2) The high public purchasing power

3) The low level of crime in MSMEs in Baturaja City (fraud, theft, etc.)

4) Consumers who have certain tastes from consumer needs

5) The existence of a program from the Regional Government to increase the potential of MSMEs in Baturaja City

b. Threats consist of:

1) The existence of similar businesses, causing competition in business

2) The inflation rate continues to increase every year

3) There is still a lack of legal protection for MSMEs in Baturaja City from trade monopolies

4) The complexity of the funding procedure with soft interest which makes it difficult for business actors to obtain working capital

5) It is expensive to rent a place of business

Table 5. MSMEs Development Strategy SWOT Analyst

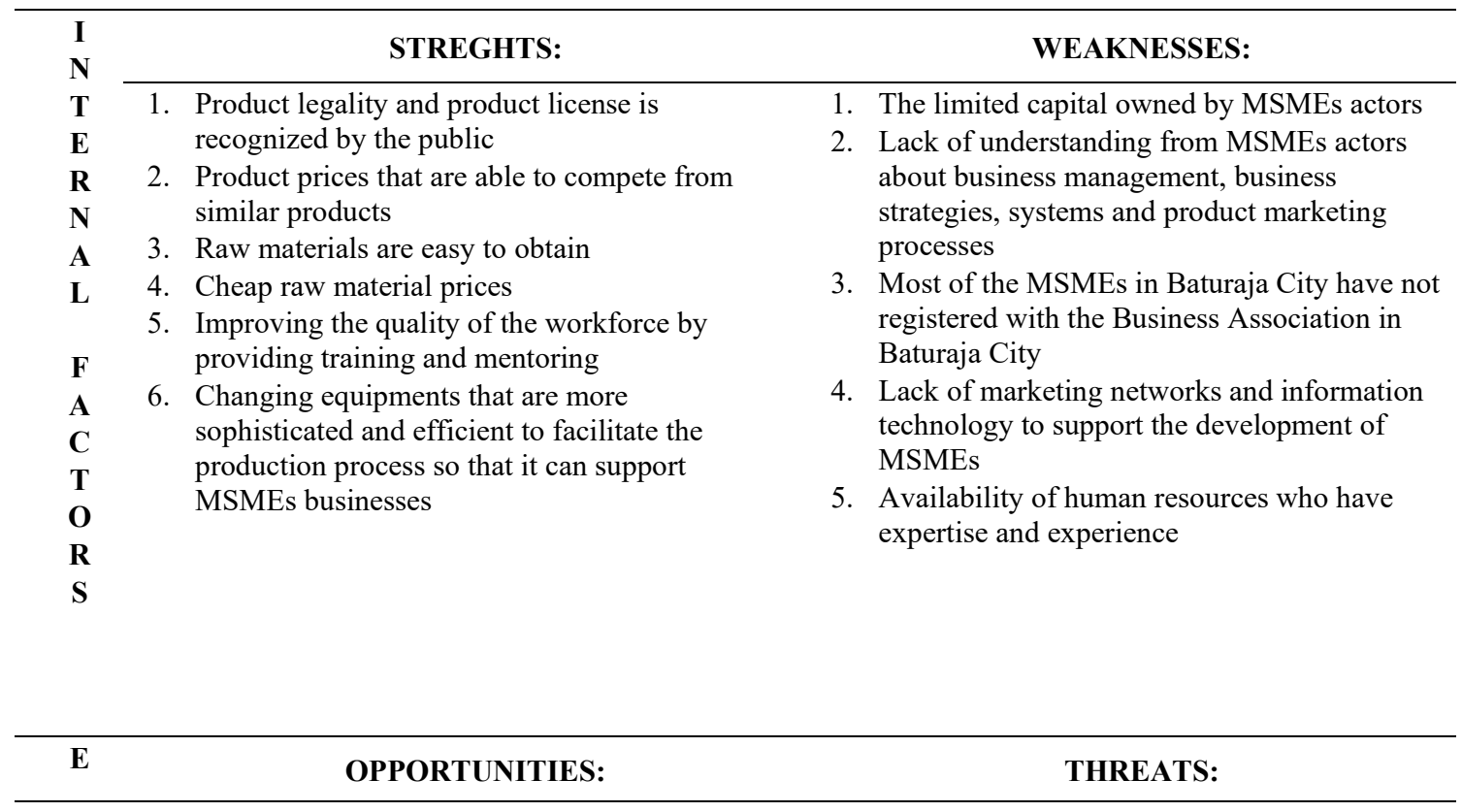




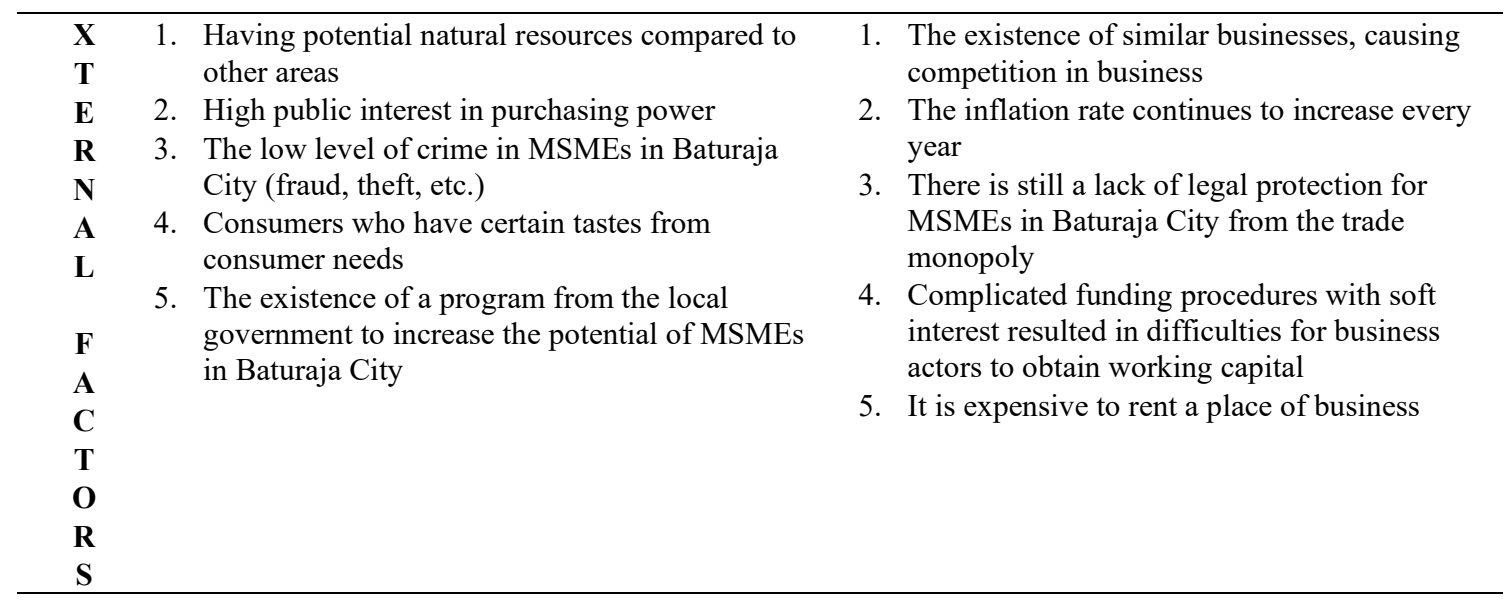

Based on the results of the SWOT analysis above, it shows that MSMEs in Baturaja City can be determined by a combination of internal and external factors. For this reason, there is a need for a strategy for developing MSMEs with a coaching and mentoring approach from the results of the analysis as follows:

\subsubsection{Forming a Business Group}

Businesses that are driven individually have the influence of slow capital accumulation. On its own, it is impossible to control the distribution of products and raw materials. This can be overcome if in one environment with similar products put together in a business group container. This strategy allows MSMEs to have the power to control distribution.

The formation of groups or organizations can also be directed at gaining access to capital to financial institutions and building a larger and more profitable business scale. Forming groups will also facilitate partnerships with other parties. With group unity, community empowerment will also be achieved.

\subsubsection{Development of Business Networks, Marketing and Partnerships}

Developing business networks can be done by forming patterns such as subcontracting clusters and partnerships. This network pattern has been formed but is not working properly.

Many business actors are not tied to subcontracting networks or partnerships with large companies, so their business existence is very vulnerable. The advantage of the subcontracting pattern is that MSMEs will continue to be suppliers of goods needed by large enterprises.

Partnerships with large entrepreneurs are also important, because empowering MSMEs does not mean eliminating the existence of large companies. Empowerment must have a strengthening value for all parties and be mutually beneficial.

\subsubsection{Human Resources Development (HRD)}

Human resources are an important factor that must be developed in any type of business. Especially for MSMEs so that they can compete with other business actors. Improving the quality of human resources can be done through training, seminars, education, workshops and business cooperation. After that, it was continued with assistance from related agencies. 


\subsubsection{Promotion}

Product promotion is a very important MSMEs development strategy. The steps include:

a. Produce a unique product

Quality alone is not enough to make MSMEs products an option. Products must also meet community needs and be unique.

b. Retaining old customers and trying to get new customers

Establishing relationships with old customers can be done through giving gifts or special promotions. Meanwhile, follow up with new customers

c. Do direct promotions

Direct product publication can be done to ivent exhibitions, bazaars, or opening stands with mini displays in public places. Show products along with information on prices, materials, and location for business establishment.

d. Create a marketing message

Marketing messages can be manifested with a tagline, mascot, certain colors that make people remember the products they produce.

\section{Discussion}

Based on the results of the analysis of internal factors and external factors on MSMEs in Baturaja City, in the SWOT analysis, it can be found that MSMEs actors must form business groups. With the aim that this strategy allows MSMEs to have the power to control distribution. Furthermore, developing business networks, marketing, and partnerships with the aim of facilitating product promotion and expanding the partnership network in distributing their products. Finally, the development of human resources or manpower also needs attention, because business management will be successful if there are competent human resources in running the organization to achieve their respective goals.

\section{Conclusion}

For MSMEs in Baturaja City, the role of the local government is very influential for the sustainability of their businesses. In addition to product improvements, prices, distribution and promotion, training and assistance are also needed in this regard. This is where the role of the government is very important to encourage the advancement of MSMEs in Baturaja City. The government's role can be in the form of support both morally and materially, as well as the provision of trainings for MSMEs actors in order to gain new knowledge that can be applied. Furthermore, it is given assistance so that MSMEs actors can run conducive and directed in developing their business.

\section{References}

[1] Alyas, M. R.: Strategi Pengembangan Usaha Mikro, Kecil Dan Menengah Dalam Penguatan Ekonomi Kerakyatan (Studi Kasus Pada Usaha Roti Maros Di Kabupaten Maros), J. Sosiohumaniora, vol. 19, no. 2, pp. 114-120, (2017).

[2] Rianse, U. and Abdi:Metodologi penelitian sosial dan ekonomi: teori dan aplikasi. Bandung: Alfabeta, 
(2008).

[3] Hikmawati, F.:Metodelogi Penelitian. Depok: Rajawali Pers, (2017).

[4] Sudaryono, S.:Pengantar Bisnis: Teori dan Contoh Kasus. Yogyakarta: CV Andi Ofset, (2015). 